
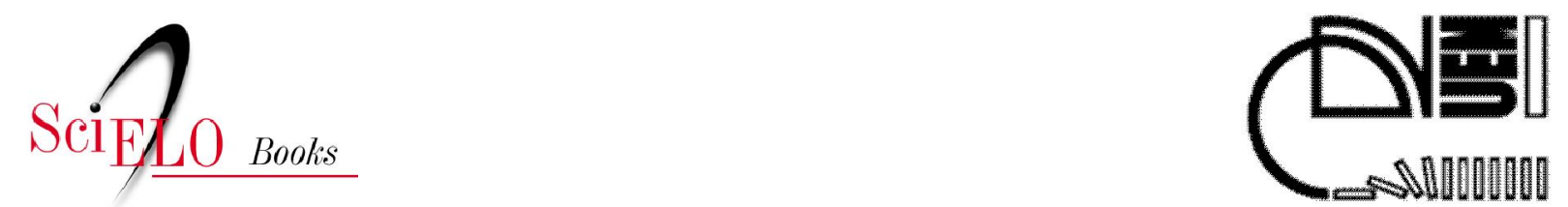

\title{
Misoginia e anticomunismo na xilogravura de cordel
}

\author{
Cláudia Rejanne Pinheiro Grangeiro
}

SciELO Books / SciELO Livros / SciELO Libros

GRANGEIRO, CRP. Misoginia e anticomunismo na xilogravura de cordel. In TASSO, I., and NAVARRO, P., orgs. Produção de identidades e processos de subjetivação em práticas discursivas [online]. Maringá: Eduem, 2012. pp. 161-181. ISBN 978-85-7628-583-0. Available from SciELO Books $<$ http://books.scielo.org $>$.

\section{(1) (1) $\Theta(9)$}

All the contents of this chapter, except where otherwise noted, is licensed under a Creative Commons Attribution-Non Commercial-ShareAlike 3.0 Unported.

Todo o conteúdo deste capítulo, exceto quando houver ressalva, é publicado sob a licença Creative Commons Atribuição Uso Não Comercial - Partilha nos Mesmos Termos 3.0 Não adaptada.

Todo el contenido de este capítulo, excepto donde se indique lo contrario, está bajo licencia de la licencia Creative Commons Reconocimento-NoComercial-CompartirIgual 3.0 Unported. 


\section{MISOGINIA E ANTICOMUNISMO NA XILOGRAVURA DE CORDEL}

Cláudia Rejanne Pinheiro Grangeiro ${ }^{26}$

\section{Introdução}

As reflexões sobre discurso, imagem, sujeito e identidade que se seguem são parte constitutiva da nossa tese de doutoramento intitulada Discurso politico no folheto de cordel: $A$ "Besta-fera", o Padre Cícero e o Juazeiro. Como referencial teóricometodológico tomamos a Arqueologia de Michel Foucault (1999, 1997), teórico cujas preocupações apontavam para a relação entre os poderes/saberes responsáveis, principalmente, pela produção das subjetividades contemporâneas. Também fazem parte das nossas referências os postulados do "grupo em torno de Michel Pêcheux", que considera as identidades sociais não como elementos estanques dados a priori, mas antes de tudo como "processos identitários" constituídos no e pelos discursos, bem como as reflexões de J.J Courtine (2006) sobre o papel da imagem nas sociedades contemporâneas, a qual. Segundo o autor, aponta a necessidade de um dispositivo de análise da "ordem do olhar". Em vista desta perspectiva, o trabalho consta

26 Professora da Universidade Regional de Cariri (URCA). 


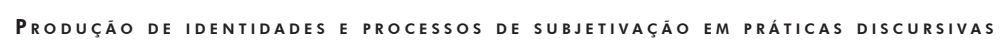

de uma análise dos mecanismos de constituição da subjetividade feminina no âmbito do discurso político. Para tanto, procedemos à análise da xilogravura da capa do polêmico folheto "Enganame que eu gosto 2", de Abraão Batista, que circulou em Juazeiro do Norte - CE por ocasião das eleições para prefeito daquela cidade em 2000, após a interdição judicial do primeiro folheto: "Engana-me que eu gosto".

\title{
Língua, discurso e imagem
}

\author{
Quanto mais longe vou \\ Mais estou voltando para casa \\ (Cora Coralina)
}

A chamada Análise do Discurso francesa (AD) preconizada pelo grupo em torno de Michel Pêcheux, a qual nasceu articulando, em regiões fronteiriças, uma leitura althusseriana do marxismo, uma leitura lacaniana de Freud e uma leitura pecheutiana de Saussure e da Linguística, por não separar teoria e intervenção política, apresentava uma teoria do discurso (sustentada ideologicamente) e um dispositivo experimental (análise automática). Assim, em princípio, o corpus a ser analisado consistia num conjunto determinado de textos ou sequências discursivas retirados mediante o processo de extração ou isolamento de um campo discursivo de referência. O objeto privilegiado da $\mathrm{AD}$ era o discurso político-partidário e o seu objetivo era encontrar a ideologia dessas formações discursivas. Para isso recortavam-se corpora verbais escritos ou transcritos e aplicava-se o método da "análise automática" para depreender as 
Terceira parte :: Misoginia e anticomunismo na xilogravura de cordel

sequências parafrásticas que constituíam os sentidos. Mais tarde, tanto a teoria quanto o método e os objetos da $\mathrm{AD}$ sofreram consideráveis transformações. Com a ascensão da mídia impressa ilustrada, da tevê e da internet, os textos contemporâneos já não se apresentam apenas em linguagem verbal, mas em sistemas híbridos, sincréticos, conjugando diversas materialidades inscritas, ainda, em gêneros de discurso diversos. Tais transformações colocam desafios para a Análise do Discurso e a necessidade de aproximações teóricas com a Semiologia. A partir de tais questões, a própria concepção de língua fundadora da Linguística como "conjunto de signos verbais" pode e deve ser rediscutida. Dessa forma, embora no momento não nos aprofundemos nesse aspecto, julgamos de alta pertinência a discussão proposta por J.J Courtine (2006), na direção de uma semiologia histórica que articule a relação necessária entre língua (numa perspectiva mais ampla que a "langue" saussuriana) e uma teoria que dê conta da imagem como materialidade contemporânea fundamental, o que nos direciona para a leitura da "ordem do olhar" e da história não como exterioridades, mas como constitutivas dos discursos semiotizados nas mais diversas materialidades.

Assim, quanto mais longe vai a Análise do Discurso em seus desdobramentos contemporâneos, mais se tem sentido a necessidade de um retorno (no sentido nietzscheano) aos fundamentos da Linguística como parte de uma ciência geral dos signos. ${ }^{27}$ Desta forma, quando Courtine (1999, p. 15) diz que "para se trabalhar com a categoria de Discurso é necessário ser linguista e esquecer que o é ao mesmo tempo", pode ser que devamos considerar atentamente essa possibilidade no sentido

27 No Brasil, há diversos grupos e pesquisadores trabalhando neste sentido. Ver os ANAIS do I e II CIAD - Colóquio Internacional de Análise do Discurso. UFSCAR. São Carlos, 2006 e 2009. Disponível em <http://www.ppgl.ufscar.br/ciad>. 
empregado pelo autor, ou seja, “esquecer” que a língua já foi estudada, desconsiderando os fatores sócio-históricos que a constituem e a tornam possível, e começar a repensar também os hodiernos desafios da ciência da língua(gem), uma das bases fundamentais da Análise do Discurso que praticamos.

\title{
Ecos de memória, vozes de sujeitos
}

\author{
Quantas vezes a memória \\ Para fingir que inda é gente, \\ Nos conta uma grande história \\ Em que ninguém está presente \\ (Fernando Pessoa)
}

Quando se fala de sujeito no interior da Análise do Discurso em autores diferentes, não se está falando da mesma coisa. Em Foucault, o sujeito é uma posição neutra, vazia, que pode ser ocupada, em distintos momentos, por diversos indivíduos, além de ser tecido - assim como o discurso - na teia de dizeres intimamente relacionados com os poderes e os saberes, como também pelas técnicas de si (materializadas pelas práticas de confissão, pelo cuidado com o corpo, etc.). Para Foucault, o sujeito não existe a priori, nem na sua origem nem numa suposta essência imanentista, portanto não há nenhum tipo de essência identitária per se. A identidade do sujeito é uma construção histórica, temporal. O sujeito, para Foucault, é disperso, descontínuo, podendo adquirir diversas posições, inclusive a de autor: "somos seres de linguagem e não seres que possuem linguagem” (FOUCAULT, 2000, pp. 20/ 21). E ainda: "No curso da sua história, os homens jamais cessaram 
de se constituir, numa série infinita e múltipla de subjetividades diferentes, que jamais terão fim e que não nos colocam jamais diante de alguma coisa que seria o homem". (FOUCAULT, 2004 p. 236, grifos nossos).

Já em Michel Pêcheux o sujeito, embora clivado, cindido, atravessado constitutivamente por outras formações discursivas, ainda está ligado às ideologias. Para Pêcheux (1997), o sujeito que enuncia o faz de um lugar social, sócio-histórico, funcionando como porta-voz dos discursos, advindo daí a ilusão de univocidade do sujeito e das formações discursivas. ${ }^{28}$ Não obstante, essa univocidade é desfeita no momento em que se inicia o trabalho de desenredar os fios descontínuos e ininterruptos tecidos pelos discursos. Isso quer dizer que as formações discursivas não são homogêneas, ao contrário, elas são traspassadas e entrecortadas por saberes/dizeres produzidos em outras regiões cujos sentidos são deslocados, dialogam, parafraseiam-se, transformando-se, reelaborando-se, fazendo com que todos os trajetos de uma região a outra pareçam possíveis. Elas são recuperáveis por meio do interdiscurso, da memória discursiva - definida por Pêcheux (1999) como

28 Não nos vamos aprofundar neste debate por não ser objetivo deste trabalho. Por enquanto parece-nos suficiente admitir uma proximidade teórica entre estes dois autores quanto à ideia de discurso como prática social, bem como o anti-humanismo de ambos em conceber um sujeito "fora de si", ou seja, um sujeito descentrado, atravessado por outros dizeres e não como agenciador consciente do seu próprio discurso. A propósito dos "diálogos e duelos" epistemológicos entre os autores ver GREGOLIN, M. R.V. Foucault e Pêcheux na construção da análise do discurso: diálogos e duelos. São Carlos: Editora Claraluz, 2004 e GRANGEIRO, C.R.P. Foucault, Pêcheux e a formação discursiva In: BARONAS, R. L. (Org.) Análise do discurso: apontamentos para uma história da noção-conceito de formação discursiva. São Carlos, SP: Pedro e João Editores, 2007. 


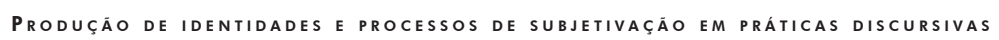

Aquilo que, em face de um texto que surge como acontecimento a ler, vem restabelecer os 'implícitos' (quer dizer, mais tecnicamente, os pré-construídos, elementos citados e relatados, discursos-transversos, etc.), de que sua própria leitura necessita: a condição do legível em relação ao próprio legível. (PÊCHEUX, 1999, p. 54 - aspas do autor, grifos nossos).

Assim, todo dito é um 'já-dito’ em outro lugar que atua de forma decisiva no processo de memória/esquecimento, responsável pela ativação de determinadas representações culturalmente construídas, arquivadas na memória discursiva, cultural e sócio-histórica, e pela produção e interpretação dos efeitos de sentido contidos nos diversos enunciados.

Para Courtine (2006, p. 88), o discurso político é um lugar de memória e a memória é, ela própria, um poder. $\mathrm{O}$ autor toma de empréstimo um termo de Pièrre Nora, que assim define o lugar de memória:

\footnotetext{
O que nós chamamos de memória é, de fato, a constituição gigantesca e vertiginosa do estoque material daquilo que nos é impossível lembrar, repertório insondável daquilo que poderíamos ter necessidade de nos lembrar [...]. À medida que desaparece a memória tradicional, nós nos sentimos obrigados a acumular religiosamente vestígios, testemunhos, documentos, imagens, discursos, sinais visíveis do que foi, como se esse dossiê cada vez mais prolífero devesse se tornar prova em não se sabe que tribunal da história. (NORA, 1993: p. 15).
}

Não obstante, quando Courtine (1999a, p. 72) discute a questão da memória, ele o faz na perspectiva do que chama de 'memória discursiva'. Partindo do ponto de vista do enunciado como 'acontecimento discursivo', a memória discursiva é concebida, assim, como a articulação entre singularidade e repetição. Tudo que é dito é necessário que já tenha sido dito, e esse dizer jamais é repetido. É necessário que algo já tenha sido dito e esquecido, apagando-se certos sentidos para assim 
ressurgir e fazer outros sentidos. O que ouvimos, pois, são apenas ecos, fragmentos de coisas já ditas. Para Courtine (1981), "a memória concerne à existência histórica do enunciado, no seio de práticas discursivas (...), capaz de dar origem a atos novos, no sentido de que toda a produção discursiva acontece numa conjuntura dada e coloca em movimento formulações anteriores já enunciadas."

No tocante à análise dos aspectos concernentes à memória, no âmbito da leitura de imagens, J.J Courtine (2005, 2006) cunhou o conceito de 'intericonicidade', termo que, na esteira do princípio da interdiscursividade, é a relação que o elemento icônico mantém com outros anteriormente realizados, no sentido de ativar/recalcar dizeres já ditos, ou mais precisamente, já mostrados. Segundo o autor, "de la même façon qu'ily a des mots sur les mots, ily a des images sur les images". ${ }^{29}$ A imagem fala, portanto, também com outras imagens, ativando elementos da memória discursiva de quem vê cujos efeitos de sentidos são construídos nesse jogo de memória/ ocultamento. Para o autor,

Toda imagem tem um eco, ela se insere numa cultura visual, o que pressupõe, para o sujeito, uma memória visual. A princípio, poderíamos supor que essa imagem diz respeito apenas às imagens vistas. Mas essa relação intericônica pode se relacionar, também, com as imagens sugeridas, as imagens externas, mas também internas, as

29 « Da mesma forma que existem palavras sobre as palavras, existem imagens sobre as imagens ». (Tradução nossa). O autor ainda não publicou suas elaborações sobre este tema. Nossas citações são oriundas dos seus seminários na Sorbonne-Paris IV - Saint Jacques, de outubro de 2005 a fevereiro de 2006 e de uma conferência proferida na UFSCAR, em São Carlos (SP), em 26 de novembro de 2006, por ocasião do I Colóquio Internacional de Análise do Discurso - CIAD e de entrevista concedida a Milanez, em 2005, publicada em 2006. 


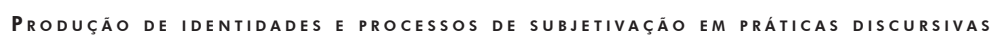

imagens de impressões visuais, imaginadas, pelos sujeitos. Imagens que nos reportam a outras imagens. O importante é que essa discussão sobre a imagem coloca o corpo no centro da análise. Portanto, a intericonicidade supõe a relação entre as imagens exteriores ao sujeito. Como quando uma imagem pode ser inscrita numa série de imagens, uma genealogia como uma série de formulações, segundo Foucault (Arqueologia do Saber). (COURTINE, 2005 apud MILANEZ, 2006, p. ??).

Assim, é considerando a imagem da xilogravura de cordel como um ícone, como um "acontecimento a ler", que a analisamos na perspectiva discursiva da intericonicidade, cujos sentidos são tecidos entre memória e atualidade. A memória, na perspectiva da Análise do Discurso, não é concebida no sentido psicológico, individual, mas presumida pelo enunciado enquanto inscrito na história a partir do qual, mobilizando toda uma rede de dizeres, ditos e não ditos, ditos e esquecidos, de imagens vistas e não vistas, o sujeito vai sendo discursivamente construído.

\section{Imagem xilográfica e cordel}

Embora a xilogravura seja reconhecida internacionalmente como arte plástica autônoma, sua origem está bastante ligada aos folhetos de cordel. Recebe o nome genérico de "Literatura de Cordel" uma extensa produção de folhetos impressos, difundidos principalmente no Nordeste Brasileiro desde o século XIX. A maioria dos pesquisadores, entre eles Diegues Jr. (1975) e Cascudo (1994), atribuem sua origem a folhetos portugueses que teriam sido trazidos para o Brasil no processo de colonização; mas vários pesquisadores 
contemporâneos discordam desta visão e atribuem a origem dos folhetos à poesia oral dos violeiros, emboladores e repentistas do Nordeste brasileiro. ${ }^{30}$

Os folhetos são pequenas brochuras geralmente impressas em papel-jornal tamanho $15 \mathrm{~cm} \times 11 \mathrm{~cm}$ e escritas em versos rimados. Antes eram comercializados nas feiras e praças públicas, mas hodiernamente adquiriram outras materialidades, como a internet - o que denominamos, em outro trabalho, de "cibercordel" (GRANGEIRO, 2006) - e apresentam uma imensa variedade temática. No tocante às discussões em torno de sua origem e história, o fato é que essa forma de expressão está presente de forma tão profunda no Nordeste do Brasil que se transformou rapidamente num dos principais elementos da cultura desta região e adquiriu funções diversas em todos os campos da sociedade, como instrumento de alfabetização, meio jornalístico e fonte histórica. É utilizada também como mídia política, por ter bastante aceitação nas diversas camadas sociais, sobretudo nos setores populares. Segundo Chartier (1990, p. 23-24), no processo de constituição da interpretação em que se articulam autores, textos e leitores - o conteúdo (denominado pelo

30 Há um grupo de pesquisadores sobre Literatura de Cordel, entre os quais me incluo, autodenominado "Movimento pela Diferença Nômade", desenvolvendo pesquisas que vêm, paulatinamente, desconstruindo as concepções tradicionais do cânone dos estudos sobre cordel, as quais, em sua maioria, apontam esta prática cultural como oriunda de Portugal, como poesia escrita e feita por homens. O Movimento considera que tais parâmetros de estudo estão baseados, em sua maioria, em princípios eurocêntricos, grafocêntricos e androcêntricos. Para estes pesquisadores contemporâneos, o Cordel é o "produto tardio" (Ria Lemaire) de toda uma tradição da oralidade, além do cancioneiro universal, do universo da poesia oral do Nordeste brasileiro, com sua imensa gama de cantadores, emboladores, repentistas, poetas, declamadores, etc. De acordo com Santos (2009), ao se considerar o Cordel como parte dos processos da oralidade é que se torna possível a audição das vozes femininas nesse universo desde o século XIX, como autoras tanto de literatura de Cordel quanto de cantorias. 


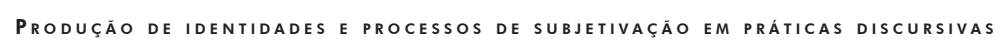

autor de mise en texte) do material que se dá a ler não pode ser desvinculado da sua materialidade, do mise en livre/mise en Page; ou seja, a colocação dos tipos, o tipo de impressão, a hierarquização dos seus elementos, tudo isso oferece ao leitor determinados protocolos de leitura.

Em outras palavras, no processo de produção/recepção de determinado conteúdo de leitura, é importante levar em consideração também as materialidades que em determinados contextos são mais eficazes que outras. No caso do folheto de cordel, por exemplo, embora não pertença aos gêneros tradicionais em que se veiculam discursos políticos, verificase que esse tipo de "mídia" possui uma aceitação maior em Juazeiro do Norte pelos seus leitores potenciais, do que, por exemplo, panfletos ou outro gênero mais tradicionalmente "político", o que provavelmente não ocorreria em outra região do país.

Esse gênero híbrido traz as duas formas de expressão: a poesia e a xilogravura, principal forma de ilustração das capas dos folhetos. Os primeiros cordéis não traziam xilogravuras. As ilustrações eram feitas por meio de clichês, de zincogravura ou litogravura. Essa técnica surgiu depois do aparecimento dos folhetos.

A palavra xilogravura vem do grego xylon (madeira) e graphein (gravar), portanto significa 'gravura em madeira'. A imagem xilográfica é talhada em madeiras leves - como umburana, pinho, cedro, cajá e outras -, com tesoura de uma perna só, banda de gilete, quicé (faca de cortar fumo), formão ou canivete, ou, conforme afirma Lopes (1982), com "qualquer instrumento cortante, desde que tenha fio afiado suficiente para abrir os sulcos e deles tirar as crenças e tradições caboclas 
Terceira parte :: Misoginia e anticomunismo na xilogravura de cordel

vestidas de anjos ou demônios, de gente ou bichos, de heróis e bandidos". Em seguida, o "taco" é embebido em tinta e transferido para o papel como uma espécie de carimbo. No Nordeste, os precursores dessa arte (Inocêncio da Costa Nick (Mestre Noza), Walderêdo Gonçalves, Antônio Relojoeiro e outros) - são da região do Cariri cearense.

A xilo em questão foi veiculada em Juazeiro do Norte CE como capa do folheto intitulado Engana-me que eu gosto 2, de Abraão Batista, em setembro de 2000, por ocasião das eleições municipais. O folheto é composto de dois volumes. ${ }^{31}$ Essa eleição foi um marco na história de Juazeiro, pelos elementos sóciohistóricos e do imaginário coletivo que mobilizou e pelo fato de que, pela primeira vez na história política desta cidade, uma mulher de esquerda, neófita em política, ameaçou a hegemonia dos grupos políticos tradicionais que se revezavam no poder havia quase 70 anos. Havia quatro coligações, no entanto a disputa eleitoral foi polarizada entre duas de matizes ideológicas à época diferenciadas: a frente encabeçada pelo PFL (Partido da Frente Liberal, hoje Democratas - DEM), com o candidato Carlos Alberto da Cruz, e a Frente de Esquerda PT/PSTU, encabeçada por Maria Íris Tavares. O cordel foi a resposta do autor a uma fala da candidata do PT em que critica a administração do Centro de Cultura Mestre Noza, propondo transformá-lo numa cooperativa de artesãos.

Juazeiro do Norte é uma cidade de aproximadamente 250.000 mil habitantes, localizada no Vale do Cariri, Extremo Sul do Ceará, a $550 \mathrm{~km}$ de Fortaleza. É nacionalmente conhecida por causa das romarias a Nossa Senhora das Dores e ao Padre Cícero

31 A Análise do primeiro folheto será publicada na forma de artigo intitulado O sujeito político feminino nas trilhas de memória da xilogravura de cordel na próxima Revista da ABRALIN. 
Romão Batista, polêmico personagem histórico, considerado santo por uma grande parcela da população do Nordeste, principalmente por causa do chamado "fenômeno da hóstia": em 1889, no momento em que o padre oferecia a comunhão a uma jovem devota conhecida por Beata Maria de Araújo, esta não pôde deglutir a hóstia, pois esta se transformou em sangue. Antes desse fato, Padre Cícero declarara, no primeiro inquérito instituído pela Igreja Católica para apurar outros fenômenos ocorridos com Maria, que esta já havia, em outras ocasiões, apresentado os estigmas da crucificação de Cristo. Tal fenômeno gerou um choque entre a política de romanização da Igreja no século XIX na difusão do culto aos santos europeus e maior fundamento doutrinário entre os fiéis e o catolicismo popular prenhe de ladainhas, benditos, procissões e promessas aos santos populares (GRANGEIRO, 2002).

Desta forma, o Padre Cícero, mesmo nunca tendo sido reconhecido como santo pela Igreja Católica, é considerado como tal pela população do Nordeste, constituindo-se como mito fundador da cidade. Neste sentido, todo o conjunto de enunciados que se constituiu em torno da figura do Padre Cícero construiu a santidade do padre como um elemento "fundador de discursividade" (Foucault, 1999) na cidade. Desta forma, todas as regiões do dizer (o comércio, a mídia, a escola, o discurso político), para enunciar, para legitimar o seu próprio discurso, em Juazeiro, normalmente se baseiam na autoridade do Padre Cícero. 
Terceira parte :: Misoginia e anticomunismo na xilogravura de corde

Misoginia e anticomunismo num caldeirão de memórias

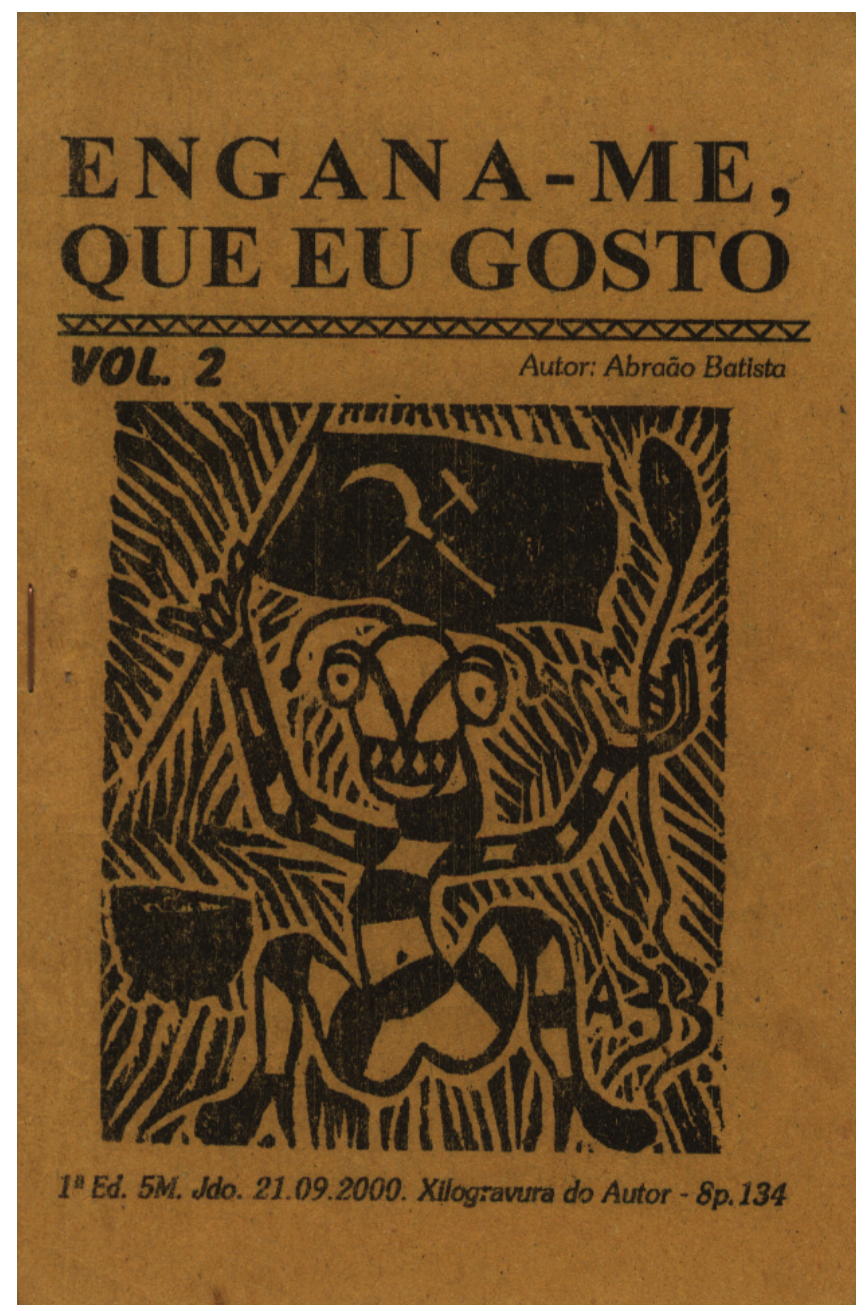

Figura 1 - Xilogravura Engana-me, que eu gosto. 
No processo de desqualificação do discurso da candidata do PT, a imagem xilográfica lançou mão de uma caricatura da imagem desta candidata. A caricatura (do italiano caricare carregar, no sentido de exagerar, aumentar algo em proporção) é um desenho que enfatiza e exagera as características de alguém de forma humorística, além de acentuar gestos e hábitos particulares a cada pessoa. A caricatura é herdeira do Expressionismo, movimento segundo o qual a arte expressaria os aspectos que a índole e a alma deixam na face da pessoa. A caricatura da xilo em questão cria um efeito de derrisão, procedimento comum no discurso político. De acordo com Bonnafous (2003, p. 35), "a derrisão é a associação do humor e da agressividade que a caracteriza e a distingue da pura injúria. [...]"; é, pois, uma forma de "desqualificar o outro por meio do ridículo" (BONNAFOUS, 2003, p. 37).

Podemos dividir a imagem em duas partes: rosto e corpo. $\mathrm{O}$ rosto faz sentido imediatamente. Nenhum outro espaço do corpo é mais apropriado para determinar a singularidade e sinalizálo como cerne do nexo social. Por ele a pessoa é reconhecida, identificada. Dessa forma o rosto da imagem, as antenas sobre a cabeça, os olhos desproporcionais à face a ponto de se situarem fora do perímetro do crânio, além da desproporção da boca e dos dentes, constroem a imagem de uma lagarta ${ }^{32}$, enquanto o corpo mantém os traços que identificam uma figura feminina caracterizada tanto pela sinuosidade dos traços corpóreos como pelos sapatos de saltos altos. A semicobertura dos seios e outras partes do corpo que devem ser cobertas deveu-se à interdição

32 Tal fenômeno não é exclusivo deste discurso. Em BROSSAT, A. Le Corps de l'ennemi: hyperviolence et démocratie. Paris: La Fabrique, 1998, o autor discute o que chama de "animalização da política", ou "zoopolítica", no contexto francês, ou seja, trata-se de um discurso, cuja construção do inimigo utiliza-se, não raro, de metáforas animalescas tais como "raposa, rato, cão, lobo etc." 
do primeiro folheto, no qual constava uma figura demoníaca desnuda.

Quando a candidata petista é representada por uma lagarta, ativam-se na memória de quem vê a imagem dizeres outros ditos e esquecidos em outros lugares de fala. Por exemplo, no âmbito da agricultura, a lagarta é uma praga, um elemento indesejável, o inimigo natural das plantações, o que as destrói. Dessa forma, se a bandeira com o símbolo de comunismo está nas mãos de uma lagarta, o antimodelo político dessa vertente ideológica é construído a partir dessa metáfora, do deslizamento do sentido, da transferência de sentidos do universo da agricultura para o campo político. A foice e o martelo, símbolos do comunismo cunhados no século XIX, no interior da III Internacional Comunista, que significam a união dos trabalhadores do campo com os da cidade, funcionam ainda hoje como símbolo dos partidos alinhados com essa ideologia política. Não obstante, em face da não transparência dos sentidos - que podem ter diferentes significações quando enunciados em diferentes lugares da fala, - no contexto histórico de Juazeiro a utilização desses símbolos vai fazer falarem, por exemplo, os discursos do Padre Cícero contra o "comunismo ateu", e toda uma rede de dizeres em torno da demonização do comunismo será mobilizada. ${ }^{33}$

33 Este discurso anticomunista tem precedentes na história. Foi utilizado pelos nazistas para perseguir as pessoas dessa corrente ideológica, bem como para perseguir judeus, ciganos e homossexuais. No Brasil foi utilizado pelo governo de Getúlio Vargas para reprimir oponentes. Conheceu, porém, o seu apogeu, no período da ditadura militar, por causa da Doutrina de Segurança Nacional. Sobre o discurso dos militares no Brasil Ver FIORIN, J.L. O regime de 1964: discurso e ideologia. São Paulo: Atual, 1988 e INDURSKY, F. A fala dos quartéis e outras vozes. Campinas: Editora da UNICAMP, 1997. No Nordeste há um forte imaginário anticomunista, propagado tanto pelos partidos de direita como pelas religiões. A crença de que comunistas comem crianças, por exemplo, ainda subsiste. Em Juazeiro do Norte, nas eleições de 1989 para presidente foram espalhados na cidade boatos de que o então candidato Lula da Silva iria mudar a bandeira do Brasil, torná-la vermelha, que 
Outro aspecto dessa relação com a memória é a presença do caldeirão e da colher, a qual constrói uma relação entre o espaço público e o privado no tocante à figura feminina. É mediante a mobilização de um pré-construto de representação da mulher na sociedade patriarcal como inscrita no domínio doméstico que se torna possível perceber o efeito de sentido da imagem da colher, instrumento que pertence ao campo semântico de 'cozinha', lugar atribuído, nos discursos sexistas, ao gênero feminino. A colher e o caldeirão evocam o espaço doméstico, fazendo falar enunciados vivos na memória discursiva do leitor do tipo 'lugar de mulher é na cozinha'. Considerando-se, assim, o contexto em que essa mulher concorria a um cargo público, este seria incompatível com o gênero feminino. Assim, a imagem concorre para 'lembrar' qual é o lugar da mulher. O caldeirão evoca, ainda, outra representação feminina indesejada: a das denominadas 'bruxas' no discurso da Igreja Católica Medieval. Nesse contexto histórico, toda mulher poderia ser considerada bruxa, visto que as ligações demoníacas estão associadas ao gênero feminino desde o mito de Adão e Eva, em que esta conduziu aquele ao pecado, passando por toda uma rede de dispositivos sociais e institucionais. ${ }^{34}$

iria destruir a estátua do Padre Cícero. Ademais, em todas as eleições, este discurso retorna de diferentes formas, a depender do candidato. Em 2000, moradores de bairros periféricos da cidade contam ter recebido em suas casas estátuas do Padre Cícero pintadas de vermelho como se tivessem sido entregues pelo PT.

34 Não só as religiões representaram a mulher como ser que deve obediência e "aprender em silêncio, com toda a sujeição" (I Tim 2:11). Também o Direito, a Filosofia e a Medicina justificaram por muito tempo, a desigualdade entre os gêneros. Dizia Ambroise Paré, renomado cirurgião francês do século XVI, em sua Anatomie Universelle du Corps: "Se os órgãos sexuais da mulher são internos, contrariamente aos do homem, isso se deve à 'imbecilidade' de sua natureza que não pôde expelir e lançar fora as ditas partes, como no homem”. O filósofo Aristóteles (384-322 a.C.) via o gênero feminino como um defeito da natureza, "um 
Outro elemento possível de identificar na imagem é a disposição das pernas abertas da figura, o que também é constitutivo de uma representação indesejável da mulher, de acordo com toda uma tradição profundamente marcada pela ética cristã, que atribui os valores de recato e obediência a este gênero, e também com os manuais de etiqueta social, os quais apresentam as formas elegantes de se portar, de sentar, e segundo os quais sentar-se com as pernas abertas não faz parte dos dispositivos sociais de construção da subjetividade pública feminina em nenhuma época.

Desta forma, ao associar os símbolos do comunismo e um corpo feminino com "cabeça de lagarta", produz-se também um jogo de verdade/falsidade. O comunismo é falado diferentemente, de forma ressignificada, atualizando falas tanto do discurso bíblico - "Satanás é o mestre do disfarce e procura constantemente falsificar as verdades de Deus" (São Paulo, Epístola aos Coríntios 11:13-15) - como dos sermões do Padre Cícero, o qual dizia que "a besta pode assumir muitas faces, muitas vezes, até a de uma bela mulher".

É por essa via que tais elementos vão adquirir outros efeitos de sentido, na perspectiva de desqualificação do discurso da candidata petista. Ao atribuir a essa candidata o discurso comunista por meio do símbolo associado a uma lagarta, bichinho que destrói as plantações, produz-se um efeito de sentido de que aquela candidata "comunista" seria a destruição de algo sólido, já "plantado", já instituído.

macho mutilado". In: LUCAS, A. A mulher e a política. http://www.brejo.com/b8/ler. coluna.php?ArtID=270\&page=1, pesquisado em 28/02/2010. 


\section{Considerações finais}

De acordo com Foucault (1999, p. 97), “o sujeito não preexiste ao discurso, ele é construído/constituído no e pelo discurso". Nessa perspectiva, pudemos verificar os mecanismos de constituição de identidade do sujeito político feminino a partir de uma materialidade imagética, a xilogravura, atuando no sentido da desqualificação do discurso da candidata do PT nas eleições para prefeito de Juazeiro do Norte - Ceará, em 2000. Essa desqualificação ocorre por meio da construção de um antimodelo de candidatura, o comunista e feminino; ou seja, pelo discurso da imagem, um sujeito político qualificado para o cargo de prefeito seria alguém não comunista e não mulher, o que faz emergirem discursos misóginos e anticomunistas pronunciados em outros lugares de fala. Para a construção desse discurso, a imagem mobiliza, num processo de intericonicidade, aquilo que fala alhures, ativando, na memória discursiva de quem vê a imagem, elementos como a lagarta, a foice e o martelo, o caldeirão e a colher. No âmbito da agricultura, a lagarta é uma praga que destrói plantações, e no discurso político em tela esse sentido é deslocado, produzindo o efeito de sentido de que aquela prática discursiva "comunista" seria a destruição de algo sólido, já "plantado", já instituído, significando que na "lavoura" política de Juazeiro a candidata do PT, tanto por ser mulher quanto por ser "comunista", atuaria como elemento destruidor do que já estaria solidificado. Para o presente trabalho recortamos a xilogravura de cordel e a colocamos em diálogo com outros dizeres para demonstrar que esta imagem faz irromperem, de forma realçada, falas pronunciadas/impronunciáveis, ativando elementos da memória coletiva e ressignificando-os no domínio de atualidade. Não obstante, pensamos que, em face da 178 
Terceira parte :: Misoginia e anticomunismo na xilogravura de cordel

“sociedade do espetáculo" (DEBORD, 1997), em que a imagem, com seus textos sincréticos, adquire importância ímpar, essa aproximação da Análise do Discurso com o que J.J. Courtine vem denominando de Semiologia Histórica abre um imenso leque de possibilidades de análise das mais variadas materialidades, na busca do funcionamento dos discursos contemporâneos no intrincado e complexo encontro da língua (em sentido amplo) com a história, espaço no qual os sujeitos se constituem/são constituídos e (re)fazem sentido(s).

\section{Referências}

BÍBLIA SAGRADA. Edições Paulinas. São Paulo, s/d.

BONNAFOUS, S. Sobre o bom uso da derrisão em J.M. Le Pen. In:

BROSSAT, A. Le Corps de l'ennemi: hyperviolence et démocratie. Paris, La Fabrique, 1998, p. 35-48.

CHARTIER, R. A ordem dos livros: leitores, autores e bibliotecas na Europa entre os séculos XIV e XVIII. Brasília,:Ed.da Universidade de Brasília, 1990.

CASCUDO, L.C. Cinco livros do povo. 3. ed. João Pessoa: Ed. da Universidade Federal da Paraíba, 1994.

COURTINE, J.;VIGARELLO, G. A História do corpo: as mutações do olhar. v. 3,. Petrópolis: Vozes, 2006, p. 341-361

COURTINE, J.-J. Analyse du discours politique: le discours communiste adressé aux chrétiens. Languages, n. 62, pp 9-128. Paris: Larousse, 1981.

O discurso inatingível: marxismo e linguística (1965-1985). Cadernos

de Tradução. n. 6, p. 5-18. Porto Alegre, 1999.

DEBORD, G. A sociedade do espetáculo. Rio de Janeiro: Contraponto, 1997. 
Produçäo de identidades e processos de SUbJetivaçäo em práticas discursivas

DIEGUES JR., M. Literatura de cordel. Cadernos de Folclore, n. 2. Rio de Janeiro, 1975.

FIORIN, J.L. O regime de 1964: discurso e ideologia. São Paulo: Atual, 1988.

GRANGEIRO, C.R.P. O discurso religioso na literatura de cordel de Juazeiro de Norte. Crato: A Província, 2002.

GRANGEIRO, C.R.P. Transformacões do fazer a Lira Cordelina. Juazeiro do Norte, 2006. Mimeo.

GRANGEIRO, C.R.P. Foucault, Pêcheux e a formação discursiva In: BARONAS, R. L. (Org.) Análise do discurso: apontamentos para uma história da noção-conceito de formação discursiva. São Carlos-SP: Pedro e João, 2007a.

GRANGEIRO, C.R.P. Discurso politico no folheto de cordel: A "besta-fera", o Padre Cícero e o Juazeiro. Tese de Doutorado. UNESP/Faculdade de Ciências e Letras de Araraquara (SP), 2007b.

GREGOLIN, M. R.V. Foucault e Pêcheux na construção da análise do discurso: diálogos e duelos. São Carlos: Claraluz, 2004.

FOUCAULT. M. Resumo dos cursos do Collège de France. Rio de Janeiro: Jorge Zahar, 1997.

. A arqueologia do saber. Rio de Janeiro: Forense Universitária, 1999.

. Ditos e Escritos: Ética, Sexualidade, Política. Vol. 5. Rio de Janeiro: Forense Universitária, 2004.

INDURSKY, F. A fala dos quartéis e outras vozes. Campinas: Ed. da UNICAMP, 1997.

LOPES, J.R. Literatura de cordel: antologia. Fortaleza: BNB, 1982.

LUCAS, A. A mulher e a politica. Disponível em: <http://www.brejo.com/b8/ ler.coluna.php?ArtID=270\&page=1>. Acesso em: 28 fev. 2010.

MILANEZ, N. O corpo é um arquipélago: memória, intericonicidade e identidade. In: NAVARRO, P. (org.) Estudos do texto e do discurso: mapeando conceitos e métodos. São Carlos: Claraluz, 2006, p. 153-179. 
Terceira parte : Misoginia anticomunismo na xilogravura de cordel

NORA, P. Paris: La Nation. Vol. 1, 1993.

PÊCHEUX, M. Papel da memória In: ACHARD, P. et al. Papel da memória. Campinas-SP: Pontes,1999.

Semântica e discurso: uma crítica à afirmação do óbvio. 3 ed. Campinas: Editora da UNICAMP, 1997.

SANTOS, F. P. Novas cartografias no cordel e na cantoria: desterritorialização de gênero nas poéticas das vozes. Tese de Doutorado. UFPB. João Pessoa, 2009. 
